\title{
Umbilical Cord Tissue
}

National Cancer Institute

\section{Source}

National Cancer Institute. Umbilical Cord Tissue. NCI Thesaurus. Code C133318.

Tissue derived from the umbilical cord. 